\title{
FINANCIAL REPORTING SYSTEM OF ELEMENTARY EDUCATION IN GUJARAT WITH RESPECT TO SARVA SHIKSHA ABHIYAN
}

\author{
Mr. Nirav Pandya
}

\section{Abstract:}

Elementary education is basic and important phase of education. Sarva Shiksha Abhiyan project is a mission program sponsored by Ministry of Human Resource Development, Government of India to be implemented by the respective state government under their elementary education system. In Gujarat SSA is functioning from the year 2000-2001 onwards. This paper is designed to review financial and accounting aspect of the Sarva Shiksha Abhiyan mission functioning in the Gujarat by studying accounting methods and compliances by the SSA. The paper describes significant accounting and financial reporting methodologies adopted by the SSA Project in Gujarat and review of the same.

Key words: Sarva Shiksha Abhiyan, Elementary Education

\section{Introduction}

Sarva Shiksha Abhiyan (SSA) is a programme sponsored by Ministry of Human Resource Development of Government of India. SSA is functioning from the year 2000-2001 onwards in the Gujarat State. The aims of this program are to implement elementary education in a missionary mode by Gujarat Council of Elementary Education formed by the State Government of Gujarat under the Societies Registration Act. The project intended to provide basic and relevant education to all children in the age group of 6 to 14 years by 2010. Sarva Shiksha Abhiyan is an attempt to universalize elementary education by community ownership of the school and thereby SSA responses to the demand for quality elementary education all over the country as a national lookout.

\section{Objectives of SSA}

- The aim of Sarva Shiksha Abhiyan was to provide useful and relevant elementary education to all children in the age group of 6 to 14 by the year 2010 . By the active participation of the community in the school management, SSA aimed to bridge social and gender gap among children. The programme aimed to 
open new schools in those areas where schooling facilities are not available and support existing school infrastructure through provision of additional class rooms, sanitation facilities, drinking water, maintenance grant and school improvement grants.

- Existing schools with insufficient teacher strength are provided with additional teachers, while the capacity of existing teachers is strengthened by training, grants for developing teaching and learning materials and strengthening of the academic support structure at CRC, BRC and District level.

- SSA aimed to provide quality primary education including life skills. SSA has a special focus on girl's education and children with special needs. Its aim is to facilitate children to learn about their natural environment in a manner that allows the harnessing of their inside human potential both spiritually and materially. This mission must also be a process of value based learning that facilitates with an opportunity to work for each other's well-being. Sarva Shiksha Abhiyan realizes the importance of early childhood care and education.

\section{Fund Release Process}

Under the SSA Program, all the districts will prepare proposal through community owned pre-project phase based on the implementation framework. State level implementation Society will forward these proposals to the national level implementation authority for release of fund after appraisal.

The Central government will release funds to the State government. The State government would be expected to transfer this fund to the State Implementation Society within stipulated time of thirty days. After preparation of the District Elementary Education Plans, the perspective as well as the Annual Plans will be appraised by a joint team of experts constituted by the National and the State level implementation Society.

The national authority of Sarva Shiksha Abhiyan Mission will approve the Annual Plan on the basis of the appraisal report, recommendation of the State Implementation Society, availability of central plan funds, and commitment of the State government regarding financial resources. 


\section{Objectives}

- To review Sarva Shiksha Abhiyan Project in Gujarat State.

- To understand financial and accounting methods of the Sarva Shiksha Abhiyan in Gujarat.

- To review financial reporting procedures of the Sarva Shiksha Abhiyan in Gujarat.

\section{Scope of the study}

Sarva Shiksha Abhiyan Project is functioning in Gujarat State from the year 2000-2001, although; the scope of the study for this specific research is limited to the period of $11^{\text {th }}$ five year plan (2007-08 to 2011-12).

\section{Literature Review}

To carry out research in a captioned subject following literature were important to have a review over them.

In accordance with the report by EdCil, a Research Evaluation and Studies Unit Technical Support Group of SSA "Progress Overview of Research" pointed out various completed researches over Sarva Shiksha Abhiyan at national level.

Prof. Veenaben patel et al. (2012), in the research project of Sarva Shiksha Abhiyan, Study of Teachers Feedback and their needs regarding Teacher Training, studied education efficiency of Sarva Shiksha Abhiyan.

Nena, Sonal V. (2008) in the study "A study of Accounting Practices of Municipal Corporations of Gujarat State" researched over Accounting Practices of Municipal Corporations in Gujarat with objective to know government Accounting System, Fund Management and Capital Income, Accounting Practices.

\section{Research Methodology}

The present study, Financial Reporting System of Sarva Shiksha Abhiyan, primary source of data includes annual reports and SSA framework. Also secondary source of data have been taken in to account, that includes web resources, annual statements and reports prepared and maintained by State Implementation Authority of Sarva Shiksha Abhiyan. As research is 
descriptive in nature, database or descriptive approach is used for survey and fact finding inquiries relating to study.

\section{- Selection of sample procedures, sampling techniques and its size}

For the purpose of studying accounting and financial aspects the study will focus on the 5 (five) financial years, (starting from 2007-08 to 20011-12 i.e.11th five year plan) hence the sample size is 5 years. Relevant data retrieved from SSA framework and Annual Reports published by Sarva Shiksha Abhiyan, using deliberate or purposive sampling techniques as the sample size is fixed for the purpose of study, 100 percent data relevant to Accounts and Financial aspects of SSA corresponding to the duration of 11th five year plan is considered.

\section{Review of Accounting Policies and Reporting Procedures by SSA}

\section{Important Accounting Policies}

\section{- Fixed assets}

Fixed assets acquired or created by State Implementation Authority or at field levels for different programs are being treated as expenditure at the time of release of payment. Project civil works relating to construction of schools, additional classrooms, boundary wall etc., are being charged to the income and expenditure account as expenses.

\section{- Basis of Accounting}

The SSA project accounts are prepared on historical cost convention and cash basis of accounting. Income or grants are accounted for when they are actually received and expenses are recognized as and when they are actually paid. Disbursements made to Block level are treated as expenses at the time of payment. The grant received, grant returned, undisbursed grant of previous years, tender fees received, bank interest and various other incomes are accounted as income and amount expended under various activities of this programme are accounted as expenditure including payment for construction and acquisition of fixed assets.

\section{- Inventory}


Inventories of consumables and other distributable are not being valued at the end of the year, cost of these items are treated as expenses and accounted on cash basis during the year.

\section{- Government grant}

Allocation of Government grants to the project is recognized as and when it receives, i.e. on receipt basis.

\section{- Grant return}

Grant amount disbursed under a particular budget head in the specific financial year and returned as unspent or unutilized in the same specific financial year are reversed in that same budget head itself. The grant amount disbursed under particular budget head in the previous financial years and returned as unspent or unutilized in the current financial year are considered as grant returned and treated as income.

\section{- Utilization of Grant-in-Aid}

The utilization of funds received as grant-in-aid has been accounted on the basis of utilization certificate received from BRC, CRC or District level office.

\section{- Investment}

There are no investments made by Sarva Shiksha Abhiyan other than the balance maintained in the saving accounts of the banks.

\section{Financial Reporting system and Accounting Procedures}

As per the Financial Management and Procurement Manual of Sarva Shiksha Abhiyan, complete accounts in respect of the monetary transactions of the State Implementation Society in the Headquarter office. Subordinate offices are required to maintain their records in the same manner as required in a State Government offices. However, double entry system of accounting is suggested to be followed under SSA.

\section{- Accounting Records maintenance}


Accounting records and registers prescribed to be maintained by the SSA office are:

- Ledger,

- Journal,

- Cash Book,

- Register for Journals,

- Register of Advances,

- Cheque Issue Register,

- Register of Bank drafts received,

- Register of remittances made into the Bank,

- Bank statement,

- Stock Register,

- Bill Register,

- Establishment Register,

- Register of grants of advances to mobilizing agencies,

- Fixed Assets Register,

- Register of Investments,

- Dispatch Register,

- File Register

- Any other books considered necessary to be maintained with approval of State Project Director.

Books of accounts are required to be maintained according to the State Government Accounting system, in case, some of the books are not maintained by the State Government, it will be prepared within prescribed format provided with the approval of State Project office. Expenditure statement is required to be prepared and submitted to the State Implementation Office, which may further be submitted to the concerned department of Govt. of India.

Consolidated accounts showing the total income and expenditure during the specific period under the given heads of account with opening and closing balances shall required to be prepared on quarterly basis and submitted to the State Education Department and Education Department of Central 
Government. The State Implementation Society will maintain Asset Register in the format prescribed in Framework of SSA. Further the same register will also be maintained by the subordinate offices at Block Level, Cluster Level and District Level.

\section{- Register of Advance}

SSA office maintains an Advance Register as prescribed in Financial Management Manual (SSA Framework). All advances are to be entered in the advance Register. Further other advances required to be adjusted on the basis of utilization certificate issued by respective office of SSA. Utilisation Certificate of advances is obtained mandatorily after the expiry of the prescribed period.

\section{- Monitoring of advances}

The State Implementation Society, District Project Office, Block Level office and Cluster Level office will monitor the progress of adjustment of advance in hierarchical order and take necessary remedial measures for speedy adjustment of advances within prescribed time-frame. All functionaries should make sure that actual be accounted as expenditure and not the normative costs in accounting.

\section{- Account Head}

The account head is similar to budget head and account code is similar to the budget code. This should correspond to the interventions and the norm number prescribed in the SSA manual.

\section{- Cash Book}

Cash book as most important record of cash transaction; it is required to be maintained under double entry accounting system. However, as an exception, CRC and School level offices are exempted to maintain double entry system mandatorily. Further, subsidiary offices are required to maintain separate cash book for Sarva Shiksha Abhiyan and other projects. All entries in the cashbook are required to be attested by the Head of Office. In case computerized accounting software, the cash book need not be maintained 
manually, print out of the daily cash transactions should be taken and attestation thereof, is made before competent authority.

\section{- Journal}

Journal is one of the important books of account, which is maintained by the project. All entries except cash transactions are recorded in ledger. Vouchers will support all adjustment entries passed through a Journal. All journal vouchers include brief narration of each entry and the same shall be attested by the competent authority. The person in charge of accounting will check all entries of the Journal with the vouchers

\section{- Ledger}

Due to dual entry accounting system all the entries recorded are settled in the ledger accounts in computer based system. In case of manual accounting system ledger of corresponding accounts are required to be created. Ledger accounts will be closed at the month end. Monthly account of receipts and payments will be prepared after closing of the month end accounts.

\section{- Bank Reconciliation}

Bank reconciliation statement is important statement disclosing reconciliation of month end balance as per bank book and bank statement. Bank reconciliation statement on monthly basis is provided to be maintained under the project.

\section{Findings and Conclusion}

Program success is completely based on sound financial management. Appropriate and time-managed financial information provides appropriate decision making situation and thereby, physical progress of the programme can be expedited by the availability of funds and reducing delays.

The financial management system should produce timely, relevant and reliable financial information that would allow programme administrators and Government 
authorities of State and Central to plan and implement the project effectively, monitor compliance with stipulated procedures, and appraisal thereof.

The ideal system should meet following requirements and features:

- Provision for compliance to Generally Accepted Accounting Principles. A system should identify the activities necessary to achieve the programme objectives and should be capable to express these activities in financial terms.

- A system to track and analyze financial transactions in order to make accounting practices efficient.

- An appropriate arrangement to receive funds from available sources and allocate them to the functionaries involved in program implementation.

- A system that would produce sufficient information to administer the programme, and provide each level of management with regular consolidated financial information for better decision making.

- provision including internal audit, to provide reasonable assurance that:

- Operations are being conducted efficiently and in accordance with the project's financial norms.

- Materiality and relevancy of account should be maintained.

- Reliability should be maintained for financial and operational reporting;

- Project laws and regulations should be complied with.

- Arrangements for external audit of the programme at the year end on terms of reference agreed upon with the Government of India, through a statutory audit.

- Qualified personnel, including accounting and internal audit staff, with clearly defined roles and responsibilities to conduct financial management and reporting activities.

- Maintenance of bank reconciliation statement should be maintained regularly at Head office and subordinate offices.

- Adequate accounting methodology and internal control regarding utilization and distribution of funds should be established at district level offices.

- Each grant should have separate accounts and expenses should be recorded separately, so that transparency in accounting and reporting can be maintained in records. 


\title{
X. Limitations of the study
}

- As in the study titled "Financial Reporting System of Elementary Education in Gujarat with respect to Sarva Shiksha Abhiyan" there are different methods to measure the financial performance, in this connection view of experts differ from one-another.

- The scope of study is limited to 11th five year plan (2007-08 to 2011-12). Hence, findings are mostly relevant to this particular period. Thus, findings derived from the study may not be valid beyond the study period.

- Financial Reporting procedure does not depict qualitative facts relating to quality of teachers, management efficiency, quality of education and so forth.

\section{References}

1. Framework of Financial Management and Procurement Manual of Sarva Shiksha Abhiyan

2. Information retrieved from http://www.ssa.nic.in

3. Prof. Veenaben Patel, et. all (2012), Feedback of teachers and their needs regarding teacher training, A Research Project over SSA.

4. Information retrieved from http://ssa.nic.in

5. Nena, Sonal V., (2008) "A study of Accounting Practices of Municipal Corporations of Gujarat State ", thesis PhD, Saurashtra University

6. Annual budgets estimates/plans of SSA published by Department of Education GOG for the year 2007-08, to the year 2011-12

7. P C Tulsian, (2003), Advance Accountancy, TATA McGraw Hill publication

8. Information retrieved from http://gujarat-education.gov.in

9. C R kothari, (2004), Research Methodoloy (Methods and techniques), New Age International Publishers.

10. Information retrieved from http://www.edcilindia.co.in

\author{
Nirav Pandya \\ Research Scholar (Ph.D), \\ Dr. Babasaheb Ambedkar Open University, Ahmedabad
}

